\title{
（238）铜のシャルピー街辏特性によよほす水素の影等
}

川鉄技研

中井揚一。元田邦昭

山口繁之

1.はじめに

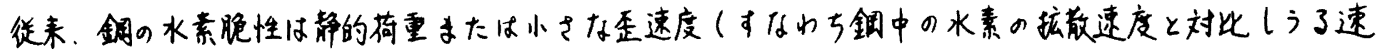

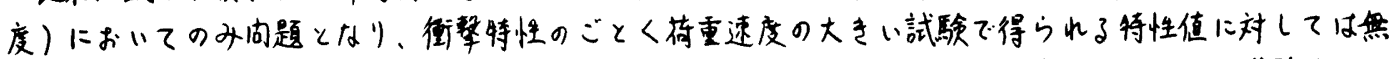

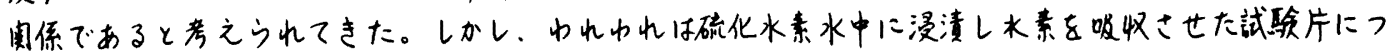

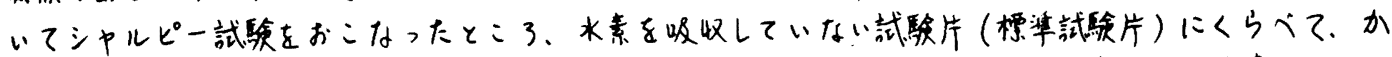
はり低いエネルギー值しか示さないことをみいたした。きうに、い,たん硫化水素水中に浸漬したのち

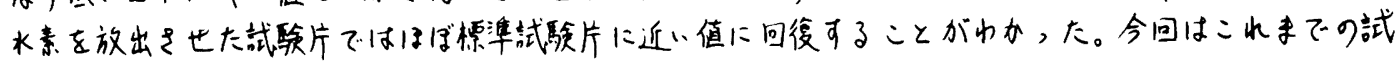

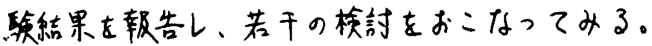

\section{2. 实䟻方法}

供試銅はA P I 賛格 X52〜X70 のラインパイプ 用圧延材が主である。シャルピー試駸はC方向につい ておこない、いくつかの試料についてはし方向につい て毛試駼した。試験片は了的4号(1部板厚のうす いものについては2/3サイズ)をもちいた。試䀢片は 次の3㮔に中けうれる。(i) そのままでシャルピー試 蒰に供したもの(標㴬試駼片) (ii) 硫化水素水中に約 60 時间浸漬したのち。ただちに試験に供したもの( 水素吸収試验片) (iii) 硫化水素水中心(ii) と同栚に浸清 したの580 ㅇ 乾燥器中に1迥间放置して水素を放 出さ世たのち試駼に供したもの(水素放出試駼片)、小 お。:のうち人部は乾㷄器に入れる前に6 $60^{\circ}$ のグリ セリン中に 72 時间浸潢して水素吸收量を测定した。

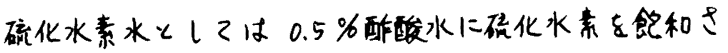
せた液をもちいた。

\section{3. 結果}

水素吸収により衝慗值代低下するものと、ほとしど 変化しないものとがある。(四1，四2）水素放出

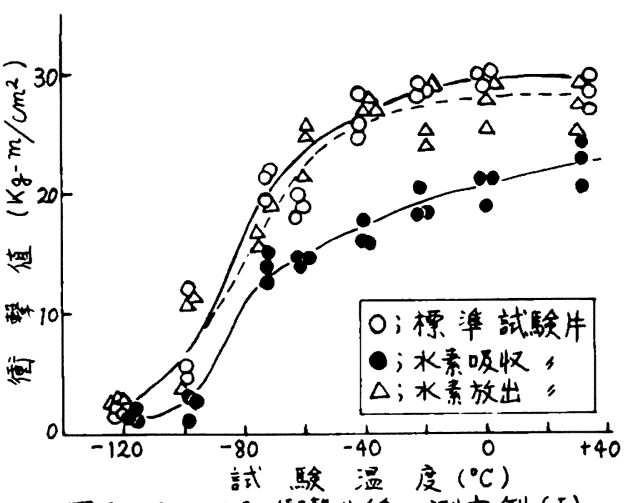

四1、シャルピー街整曲線の測定例 (I) 試料； $\times 70 ，$ 仕上圧延温度； $700^{\circ} \mathrm{C}$

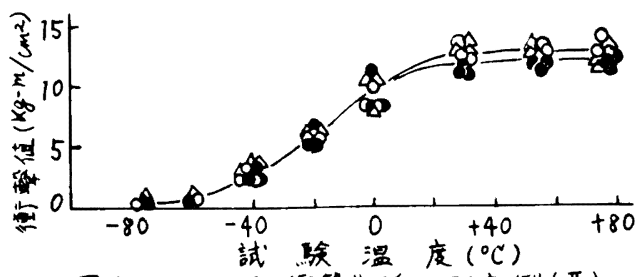

国2、シャルピー街暂曲線の测定例( II) 䳝料; $\times 52 ，$ 仕上压延温度; $890^{\circ} \mathrm{C}$

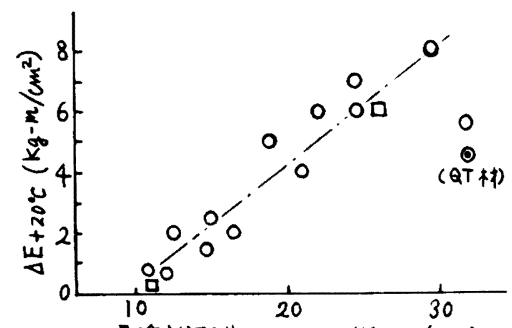

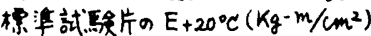

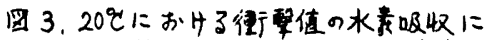
まる低下（口；し方向，他はC方向)

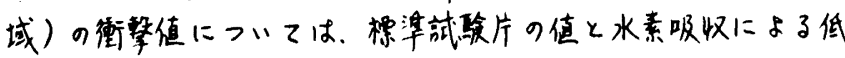
下量との间に直楾阅你がみとめられる。(国了) 
川鉄技研

1.はじめに

石油、天然ガスなどの输送パイプライン用の銅材にフいては、榆送物盾に含まれる硫化水素と水分に よる応力腐食剖れに注意せ将ばならない。た外部応力のない状態でも不りスターや圧延面に平行な内 部割れを生じ、大事故につながる危険性がある。API賛格、X52〜X70のいくつかの銅について

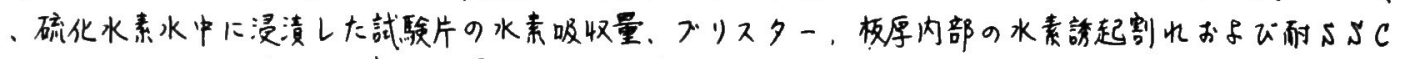
し性などについて試験し、剖れの原因について検討したので辄告する。

2. 实駼方法

硫化水素水としては $0.5 \%$ 酿酸水に硫化水素を館和させた液をも5、た。( mm（才；原板厚）の寸法に切りだし压延面以外をエポキシ檄脂でコーティングレた試駼片を用意し、 硫化水素水中に1週间浸渍したのち、水素吸収量、ズスタ一，内部剖れの测定をお:なった。水素吸 收量は $60^{\circ}$ Cのグリセりン中に72時间保持し、放出されたがス量をもって测定值とした。ズリター は、試験片表面を透明ラッカーで処理し写真撮影し、写真のコピーから光電子管法によって面棈率々伯 数を計测した。きうに試験片を10等分し、9断面につい て4倍の写真で内部制れを淠定した。割れ感受性は次式に よってあうわした。

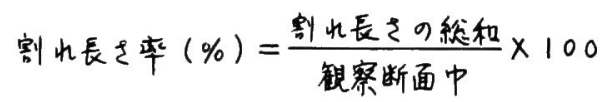

SSCC試输は $3 \times 10 \times 115(\mathrm{~mm})$ の形状のV

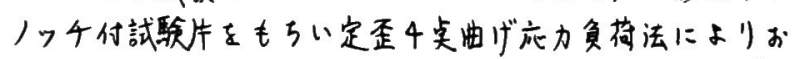
こなった。結果の整理には「Probit analysis, * を適用した。

\section{3. 結果}

水素吸収量と割中長さ率の间には相阁があるが(因1) 水素吸收量とブリスタ一の间には一定の荓係がみられない ・ブリスターの部分を断面かう稓察すると梙裂ははとんど 表面につながつてかリ、ブリスタ一内の水素は测定前に放 出それてしまっていると思われる。割れ長々率は試駼片の 厚みに依存才る倾向がある。すなっ，若干の例外を除い て、厚みの小きいものほど别れは大きく発连している。 れは极原方向の拘束力の差成送保していると推定される。 内部の割れはフェライトとパーライトの启状组线の境界 に発生している場合が多い。また介在物のつうなったとこ ろはプリス夕一や制れの発生が多く（写真1参照）。:れ らの锄織上の欠陷が水素誘起割れの主原因であると考えら 水る。

* J.P. Fraser et.al.; Corrosion 24
因1、水素誘起割れと吸收水素量の闲係

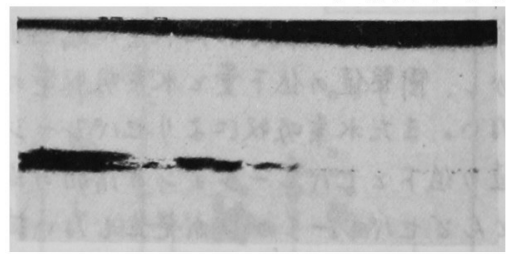

军真 し、介在物がつらなったと: に生じた剖れの例。 
（240）鋼材の板少方们特性と水紫唀起别机感受性との関係について

\section{1. 緒言}

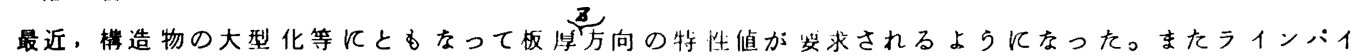

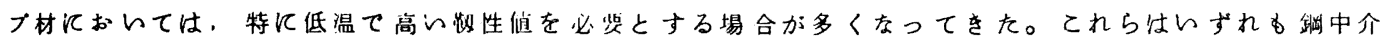
在物，特に長くのびたMnS介在物を减少させるととなとによって州決してきている。收近考案された水

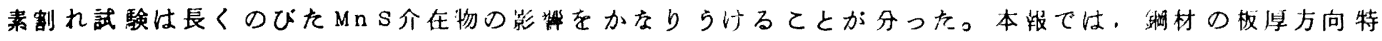
性と水素制れ試験飞つんて，主にMn S 介在物飞着目して娭討した絬果を跟告する。

\section{2. 実験方法}

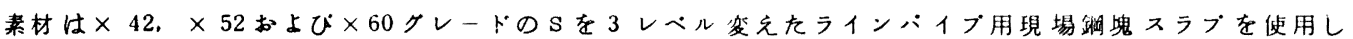

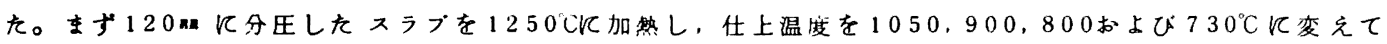
制御王延し、20n厚さに仕上湆た。

Z方向引張試験片は摩擦圧接《上り作製した丸棒型試龉片を採 用した。

水素割れ試駼片は18 t×25 w×1001（nx）飞加エし，エメリ一紙

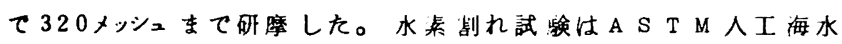
( p H 8.2) 中に試験片を唚济し, $\mathrm{H}_{2} \mathrm{~S}$ 飽和て $96 \mathrm{hr}$ 試験した。

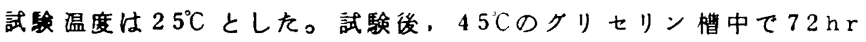
払散性水素量を則定した。割九は長さ方向に切断した 3 断面につ き調査した。

\section{3. 実験結果}

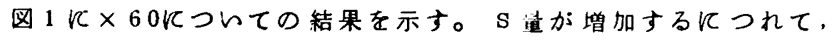
较り， $/ /$ 強度比が減少し，割れ長さが增加している。ての他て はS量が增加するにつれて伸びが減少し，払散性水素量が增加す るといら結果が得られた。

Z方向引張り特性恃主に匠延によって長くのびた MnS介在物量 に影され、これを改善するには心量を低下させるのが上んと考 えられる。

また水素咱れ試験すMnS量飞上って左右され， $Z$ 方向引張り試 雅とよく対応する上らてある。てれは水菜制れが主に長くのびた MnS介在物て発生, 成長するためと考えられる。

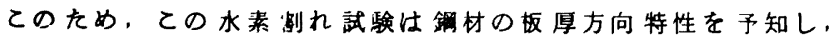
水素割れ感受性を知るらえて有用てあると考えられる。

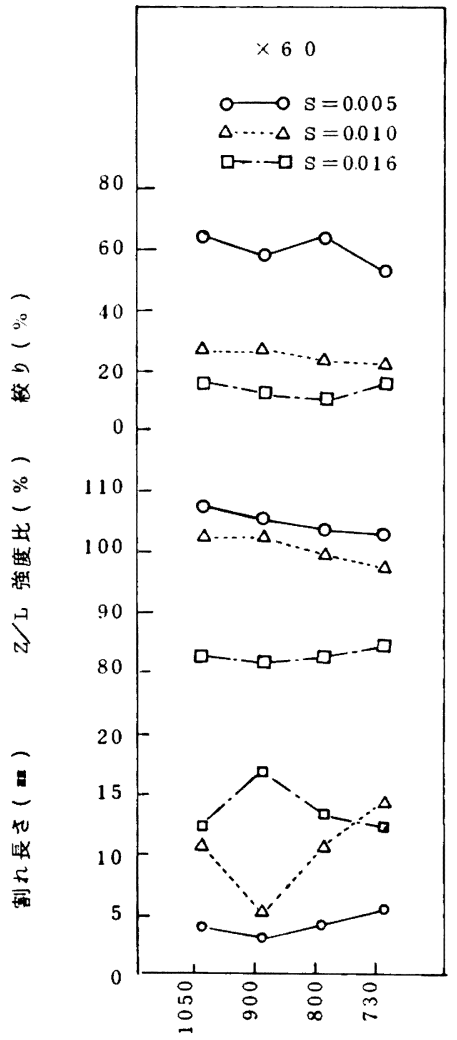

仕上り温度 $(\mathrm{C})$

図 1. 仕上り温度と $\mathrm{Z}$ 方向特性，水素割れ長さとの関係 
（241）高温高压水事によるオーステナイト系ステンレス周の内部櫣造变化

\author{
早柏田大学・理工学部回野村茂雄長谷川正萎
}

1. 粕言

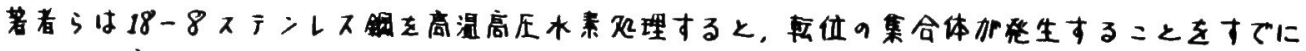

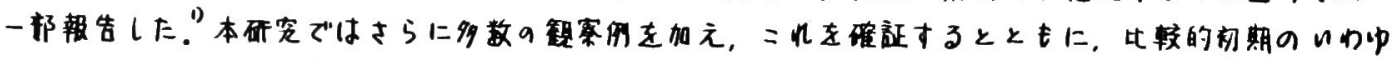

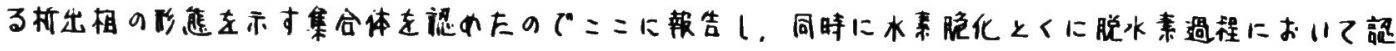

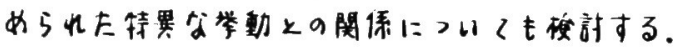

2. 実駿オ法

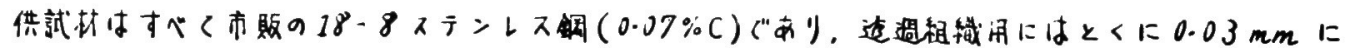

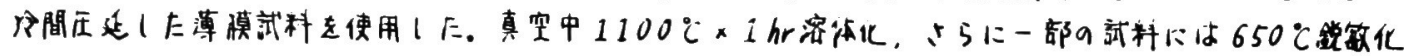

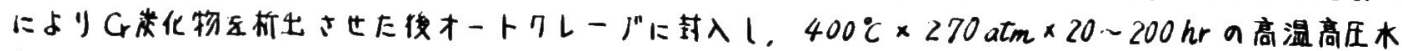

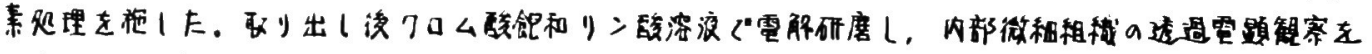

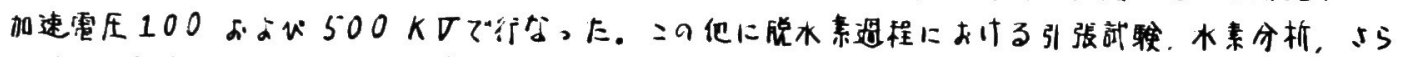

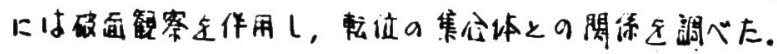

3. 粠果

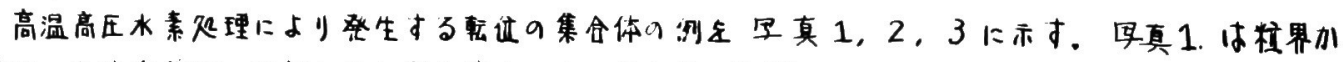

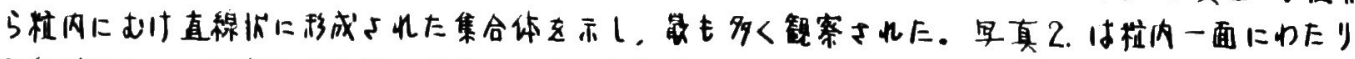

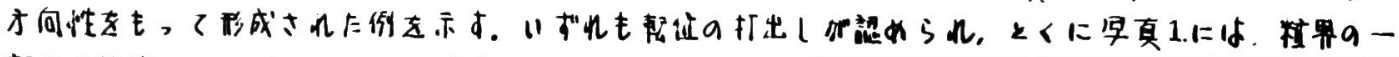

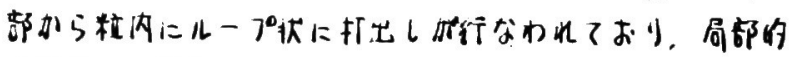

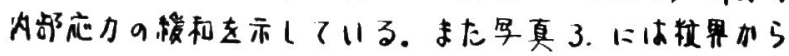
発生し上甘较的䘞期の集合体去示与。水素观理前ではまっ

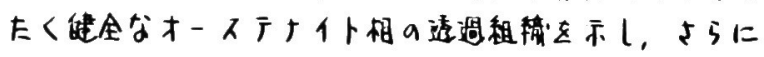

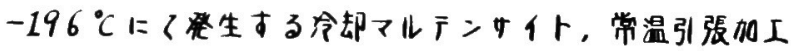

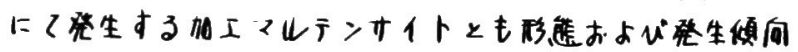

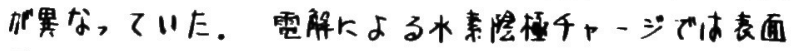

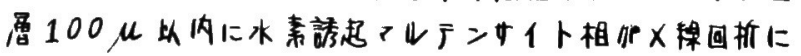

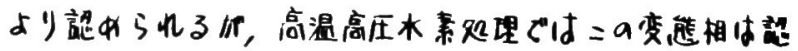
由られかか、た。

一オ水来眼化可回復週旺に むいて，高湜脱水素处理はど

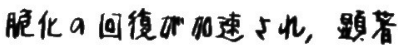
な残留水素依存性们能めら叫 ず，脆化加一部内部欠陌上起 因していると推定々れ，転值 の集分体と闌速ブけることが できた。

1) 铁上周: 59 (1973) No.14, P.1961

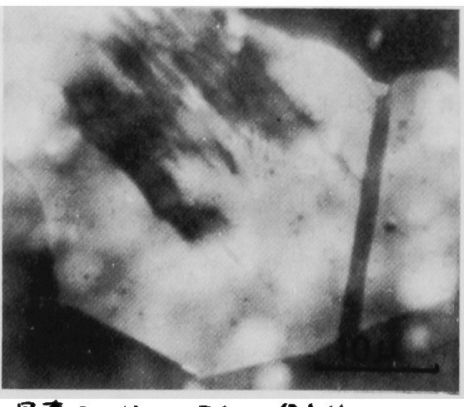

写真2 粗内上珄UE集合体

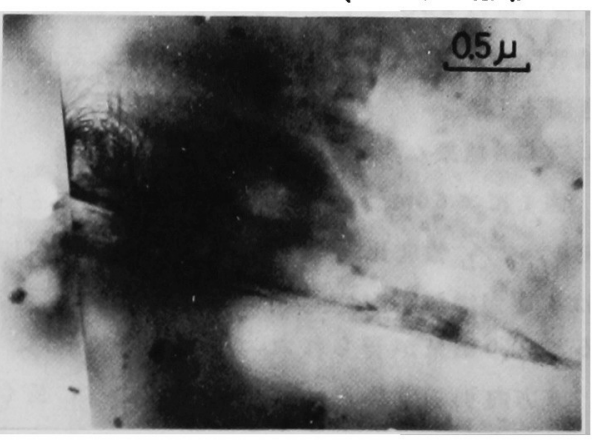

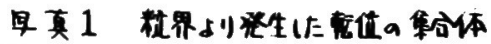

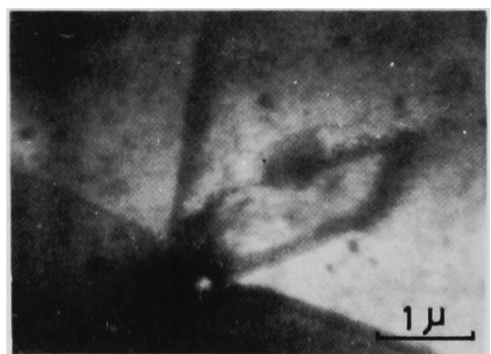

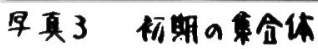




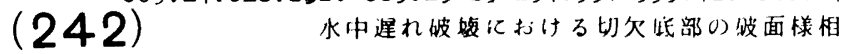

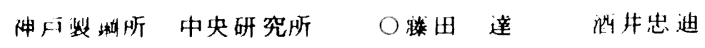

山消凯朗

1. 緒言

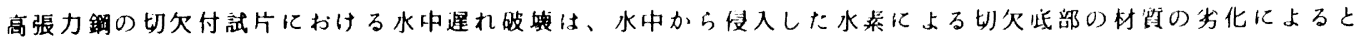

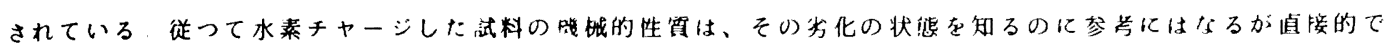

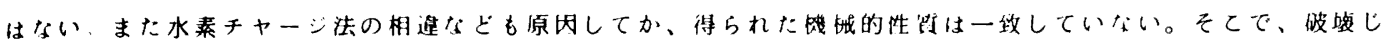

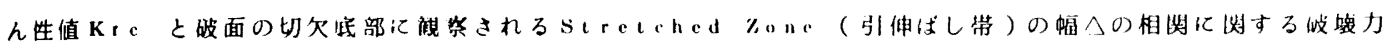

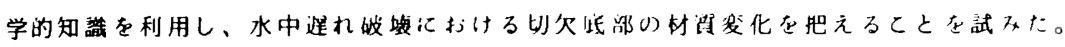

2. 実驗方法

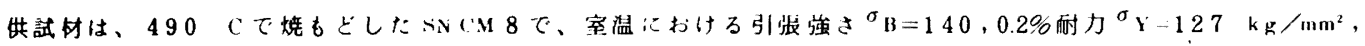

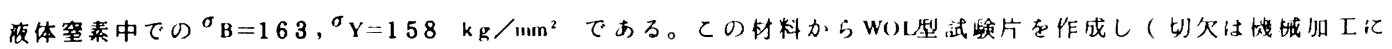
よろ

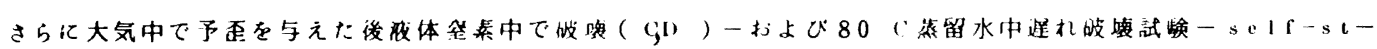

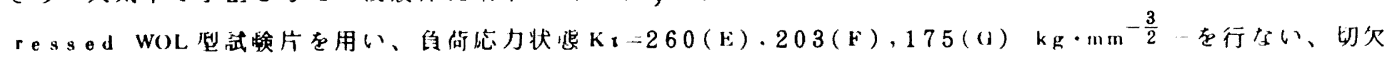

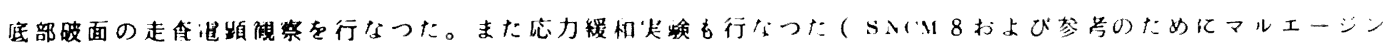
グ銅)。

\section{3. 実検結果}

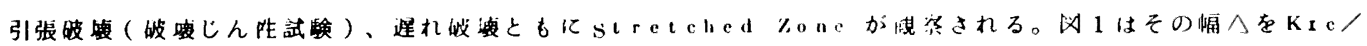

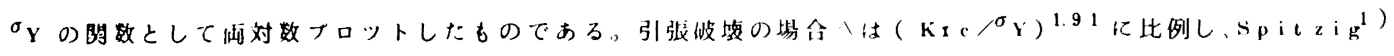
のテータと一致する。またとの結果は皮㖡力学的にも罗当

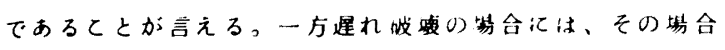
しし $\sigma_{Y}$ か変らないとし $127 \mathrm{~kg} / \mathrm{mm}^{2}$ を用いると、 $\triangle は$

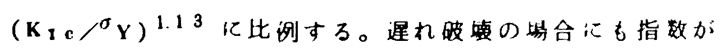

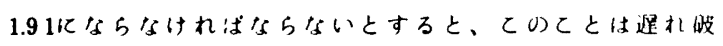

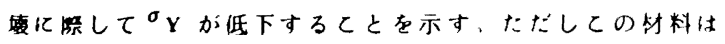

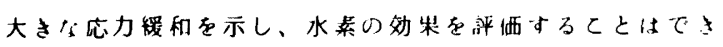

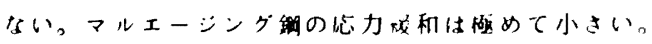

さらて、HahnとRosenfield $\left.{ }^{2}\right)$ 亿ょる

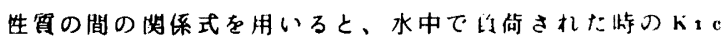

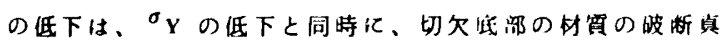
雪の著しい低下によるととかわかる。

1)W. A. Spitzig:ASTM STP 453,(1969).P. 90

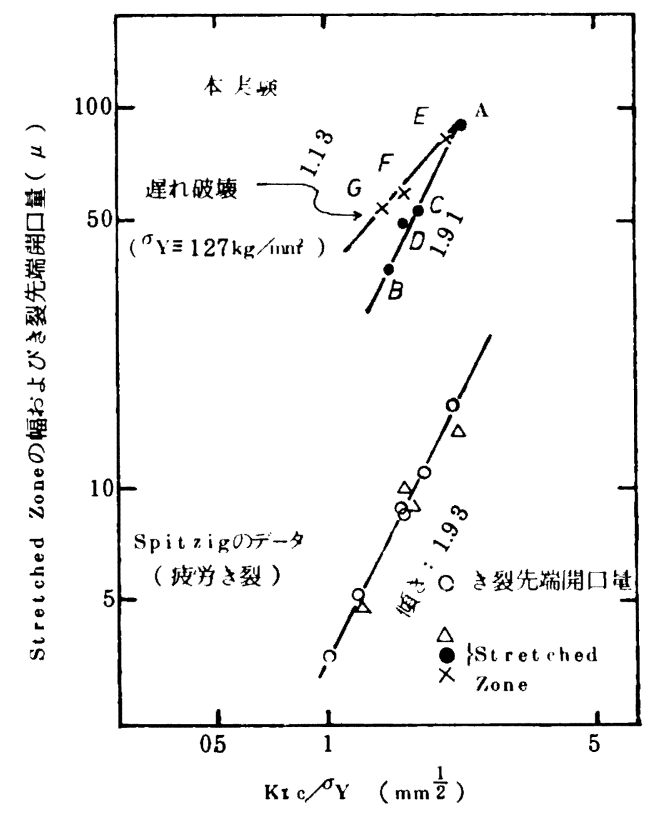

2) (1. T. Hahn and A. R. Kosenfield:ibid,432,(1968), P. 5

为 1 


\section{1. 緒 言}

高力ポルトは强度の增加により羊机破僰感受性が著しくなるが，鋼成分によってその限界応力に差の

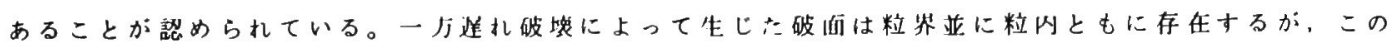

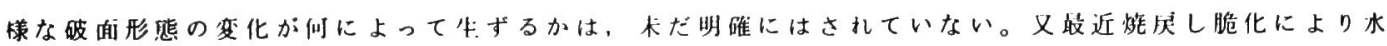

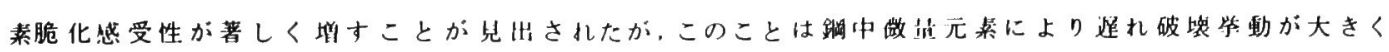

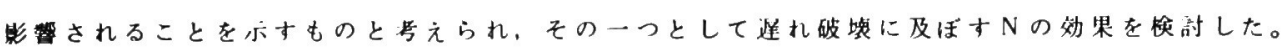

\section{2. 供試材及び試験方法}

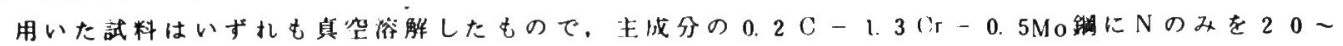

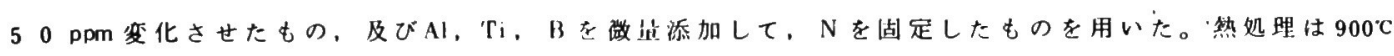

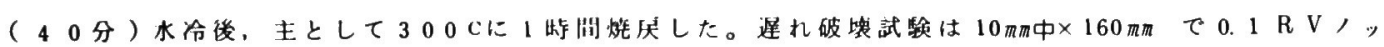

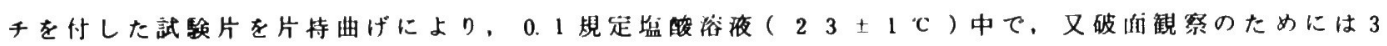
历食塩水中での电解千ャージ证によって行った。

\section{3. 実験の結果}

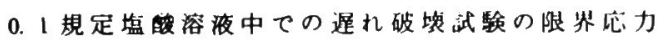
は、 $\mathrm{N}$ 量によって大きく変化する。岀は20p pm以 の $\mathrm{N}$ 添加ま〉のもの, 及びA1等の添加に上り湖定化 されていないN量をさらに堿少させたものについて 示したもので，倦者についてはAl、B添加の皆令の

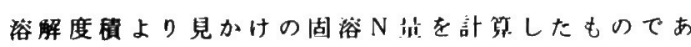
る。この結果から固定されないＮ收が增すことによ り急激な限兴応力の低下が生ずることが分る。

この様な限界応力の低下したものには,その遅扎 破增破面に粒界破面が混在してくることが熟めら机

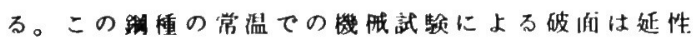
或は等開て、粒界破面を示さないことから，Nが隶 素の粒界脆化作用に大きく寄与していると 考えら礼る。そ扎ら粒内並に粒界破们の典 型例を写真に示寸。粒界破㙏は低滥能炎し 脆性の生ずる烸㞔し温度籁曲では多少增す 㖽问にあるが，通常烧㞍し脆性の生じない $200 \mathrm{C}$ 焼经しでも问梯に成り立つことが認

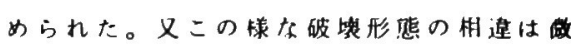
量元柋のほかに試输论力条件によっても変

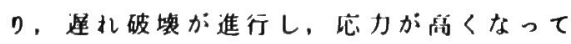
くると粒界破断が粒内破断となる倾问をも つ。

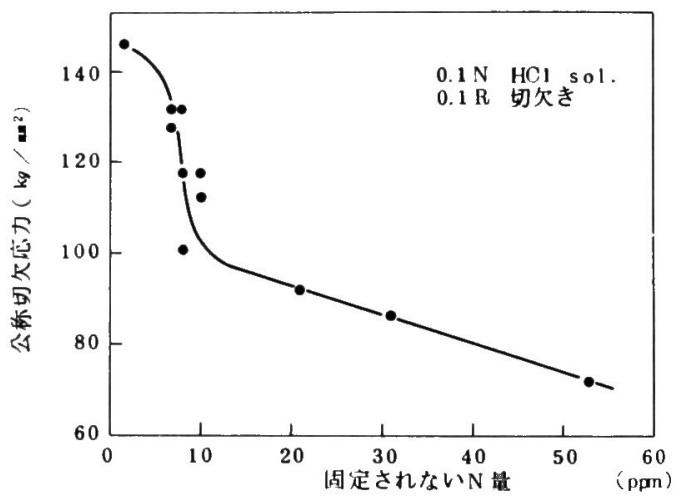

凶逢九破壊限界応力と $\mathrm{N}$ 望との関俰

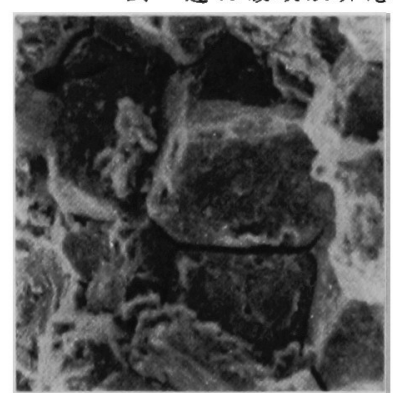

(a) $\mathrm{N}$ 添加ま > $\underline{10 \mu}$

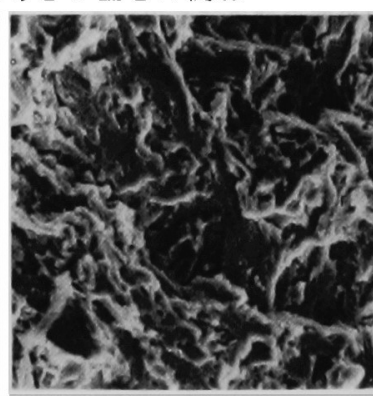

(b) $\mathrm{B}-\mathrm{N}$ 系 $\underline{10 \mu}$

实真電解千ャ一シ法による遅れ破境破面 
（244）超絵力鋼の遅れ破壊発牛:特性

住友金属工業珠

$\begin{array}{crrr}\text { 寺 } & \text { 崎 } & \text { 富久長 } \\ \text { 大 } & \text { 野 } & & \text { 鉄 } \\ \text { ○中 } & \text { 里 } & \text { 福 } & \text { 和 }\end{array}$

1. 目的：超強力鋼の遅れ破壊は、クラックの発生, 伝播, 最終破断という 3 段階に分離される。上記 3 段 階のうち, クラック発生過程を記述する特性值のひとつとして, 臨界応力拡大係数 K I SCC かあり, 超強力鋼 の実用化にとって，KISCC の大きな材料の開発は重要である。しかし K I SCC に影響を与える諸因子につ いて, 系統的な調查は, あまり行なわれていない。本㪕では, 各種超強力鋼の異種環境における KISCCを 比較し、鋼種, 強度レベル, 熱処理条件, 環境因子などについて検討した。低炭素 Mn 鍓。

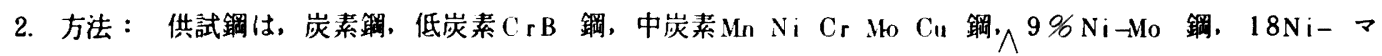
ルエージ鋼など約 10 種類の超強力鋼である。引張強さは $100 \sim 200 \mathrm{~kg} m$ 範囲で変えた。 遅れ破壊試 験は，KI-decreasing typeの定変位型試験片を用い, 試験環境としては，0.1 N-H Cl, 温水 $\left(55^{\circ} \mathrm{C}\right)$ 常温水. $3.5 \% \mathrm{NaCl}$. 自然大気中の 5 種類とした。試験は $5000 \mathrm{hr}$ 以上継続し、 K I s cC を求めた。

3. 結 果

1）図 1 KKISCC と引張強さとの関係を示す。 S3 3C+B 鋼, SAE1527+B 鋼は焼戻条件の差により引 張強さを変えた。 S33Cべース鋼P SAE1527ベース鋼の K I S C は は張強さに著しく依存し, 焼戻温度

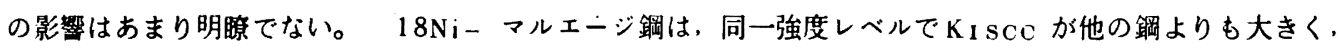

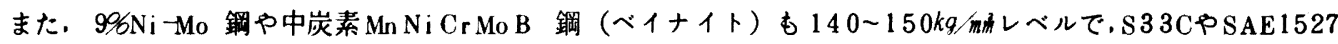
龬よりもKI S C 汃大きい。このようにKI SCC は強度レベルのみならず，鋼種によって著しく変化する。 2）図 2 は S33C,SAE51B20Mod 鋼および SAE1527 鋼を用いて, 環境因子の影響を示した。引張強さ $156 \mathrm{~kg} / \mathrm{mm}^{3}$ の SAE 1527 鋼は，5種類の環境によってKISDC はほとんど差はなく、ほほ $70 \sim 80 \mathrm{~kg} / \mathrm{mm}^{3 / 2}$ で ある。いっぽう強度の低い S33C. SAE51B20Mod鋼では, 強い環境依存性が認められる。

3）このように， $150 \mathrm{~kg} / \mathrm{mm}$ レベルのSAE 1527 鋼では, 通常大気でも K I S CC か小さく, 遅れ破壊感受性が大 きいか， $120 \mathrm{~kg} / \mathrm{mm}^{2}$ レベルの SAE5 $1 \mathrm{~B} 20 \mathrm{Mod}$ 鋼は、KI SCCが $300 \mathrm{~kg} / \mathrm{mm}^{3 / 2}$ と大きく、耐遅れ破壊性は優れ ている。

4） KI S C C は銈種や強度レベルに著しく依存するが，熱処理条件の差によるミクロ組織の変化との対応は必 ずしも明瞭でない。

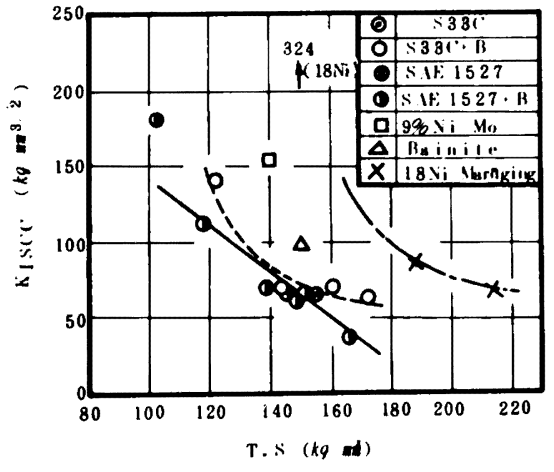

図 1 各種超強力鋼の K I SCC

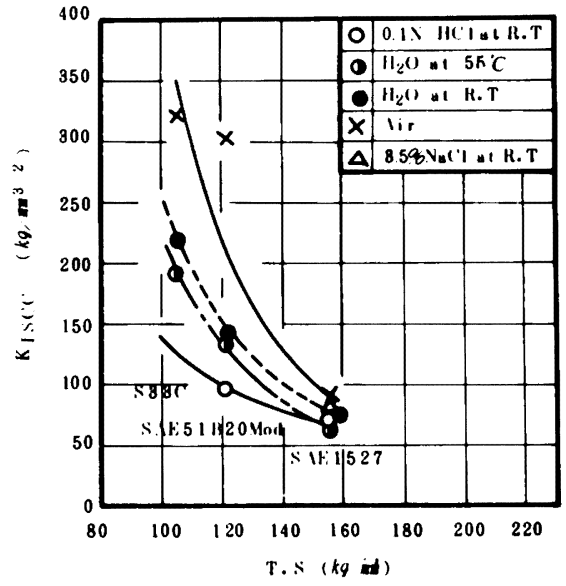

図2 KIsccの環境依存性 
住友金属工業侏中央技術研究所

1. 目的

超強力鋼を実用化するうえで要求される特性として，耐遅れ破壊性を考えるとき，もっとも重要であるのは， クラックの発生過程であり, 遅れ破壊発生特性值として, 臨界応力桩大俰数 KISCCを求めて, 構造用銅に内在 する先在疵あるいは疲労クラックなどの許容限界を求めることは，実用的に重要である。本報ではKIsccの 設計データへの応用の一例として，高力ボルトの慓準締付状態に対する破壊力学的考察から，ねじ部における 瘷許容限界の算定を試みた。

2. 方法

供試鋼の化学成分, 熱処理条件および機械的性質を表 1 亿示す。遅れ破壊試験は, 定変位型くさび㨉人式

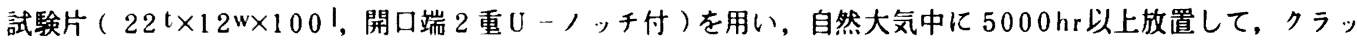
ク伝播が停止したときのクラック長さから，K心次を求めた。いっぽう高力ボルトの締付状態を，ボルトお

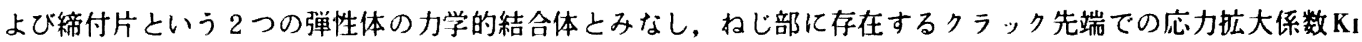
を近似計算した。両者を比較することにより，遅れ破壊発生源となり得るクラック長さを求めた。

\section{3. 結 果}

1） SAE 1527 鋼（T.S156kq/mhi) の自然大 気中における $\mathrm{KISCC} と し て, 83 k q / 1 \mathrm{k}^{3 / 2} / 2$ る值が得られた。

2) 高力ボルト(.1122) のねじ形状を半棈円 孔とみなし、ナット掛りはじめ第 1 ねじ部 谷底に存在するクラック先端の $K_{I}$ をクラ ック長さに詨して図示した。（図1） ねし形状の効果を，西谷の報告に基いて計 算した值（○印）とねじみぞをクラックと みなして計算した結果（ $\Delta$ 印）をあわせて 示した。

3）图 1 から，Xくのなる微小クラックの領域 では，ねじみぞの存在によってKI が著し く緩和されていることかわかる。

4） SAE1527 鋼を用いたT .S150 kq/mb ベルの高力ボルトは，好底に $15 \mu$ 程度 の微少晸があれば，遅れ破壊発生の危険性 がある。

その他, 遊びじ部, 不完全ねじ部につい ても, 若干の考察を行なう。現在, 疲労ク ラックを含む実物ボルトに上る稀付曝露試験 を実施し, 证許容限界の確認を進めている。

1) 西谷, 石田：日本機械学会論文集, 39 ( 1973$) 317$, P.7
表 1. 供試鋼の化学成分, 熱処理条件および機械的性質

\begin{tabular}{|c|c|c|c|c|c|c|}
\hline \multicolumn{7}{|c|}{ Chemical Composition } \\
\hline Wark & C & $\mathrm{Si}$ & Mn & $\mathbf{P}$ & S & Sol. Al \\
\hline$\$ 47$ & 0.26 & 0.27 & 1.48 & 0.019 & 0.024 & 0.032 \\
\hline \multicolumn{7}{|c|}{ Heat Treatment } \\
\hline \multicolumn{7}{|c|}{$900^{\circ} \mathrm{C} \times 1 \mathrm{hr}$} \\
\hline \multicolumn{7}{|c|}{ Mechanical Properties } \\
\hline \multicolumn{2}{|c|}{$\mathbf{Y} . \mathbf{P}\left(k q / \mathrm{mh}^{\mathbf{l}}\right)$} & \multicolumn{2}{|c|}{$\mathrm{T} . \mathrm{S}(\mathrm{kq} / \mathrm{m} \boldsymbol{m})$} & $\mathrm{E} \mid(\%)$ & \multicolumn{2}{|c|}{ R. A(q) } \\
\hline \multicolumn{2}{|c|}{132} & \multicolumn{2}{|c|}{156} & 11 & \multicolumn{2}{|r|}{42} \\
\hline
\end{tabular}

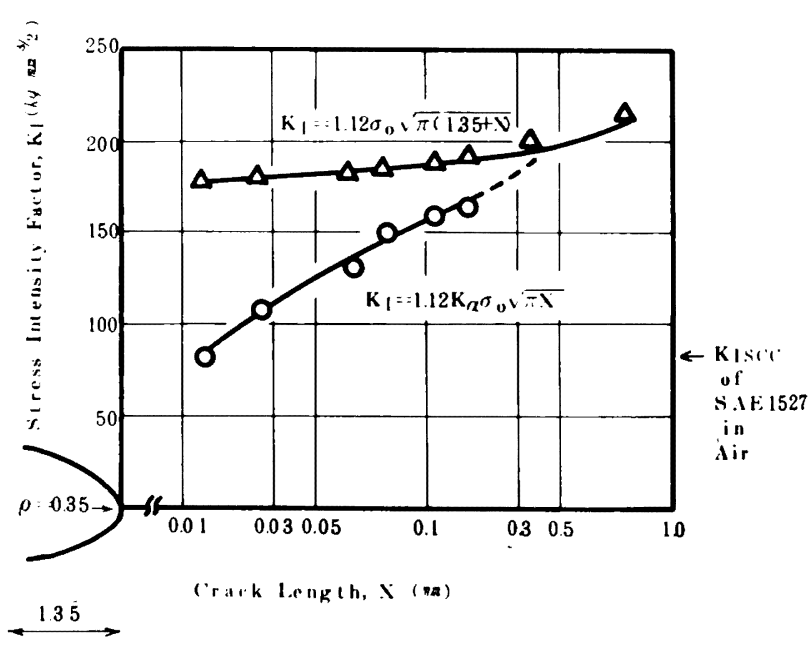

図 1.ねじ底に存在するクラック長さと応力应大係数との 関倸 